\title{
Prediction of Online Customer Satisfaction: A Case Study Go-Ride in Jabodetabek
}

\author{
Rissa Hanny, Fahrizal \\ Faculty of Economics, Universitas Pamulang, Tangerang Selatan \\ dosen01032@unpam.ac.id; fahrizallfc5@gmail.com
}

\begin{tabular}{|c|c|}
\hline & Published: 19/03/2021 \\
\hline $\begin{array}{l}\text { How to cite (in APA style): } \\
\text { Hanny, R., Fahrizal (2021). Prediction of Online Customer Satisfaction: A } \\
\begin{array}{l}\text { Jabodetabek. Jurnal Ekonomi dan Bisnis Jagaditha, Vol. } \\
\text { https://doi.org/10.22225/ji.8.1.2758.39-47 }\end{array}\end{array}$ & $\begin{array}{l}\text { Case Study Go-Ride in } \\
8 \quad(1), \quad 39-47 . \text { doi: }\end{array}$ \\
\hline
\end{tabular}

\begin{abstract}
The increasing number of online motorcycle taxis has an impact on tighter competition. PT Gojek Indonesia, which has existed since 2010, provides online motorcycle taxi transportation services based on applications under the 'GoJek' brand. This research examines how online customer satisfaction predicts service quality and brand image of Go-Ride services in the Jabodetabek area and the influence of both. This variety of causation studies serving as explanations and using the quantitative approach. Populations are passengers of Go-Ride services, located at Pasaraya Blok M, South Jakarta, that comes from that consumer in Jabodetabek area. The research sample uses purposive sampling to customer used Go-Ride's services as the counting of 96 respondents. Regression analysis technique using multiple regression. The results prove that online customer satisfaction can predict the service quality and brand image factors as Go-Ride's services yield impact partially and simultaneously. This is also reinforced by online customer satisfaction contributing 55.2 percent to predict service quality and brand image in this research.
\end{abstract}

Keywords: Online Customer Satisfaction; Go-Ride

\section{INTRODUCTION}

The mode of transportation is the medium of land, air, or sea or, in other words, tools that function as a means of public transportation (Fatimah, 2019). The flow of technological advances is a necessity that we cannot help but follow. In the digital era like today, there are many opening up new business opportunities in various fields, even businesses that did not exist before, such as online transportation services (Sugiyarto, Dewi, \& Junaedi, 2020). In Indonesia, it is often found that motorbikes also function as public transportation, namely transporting people or goods and charging an agreed fee. This type of transportation capital is known as 'Ojek' (Ihsan \& Siregar, 2019).

Since many years ago, this transportation convention has been known, especially in Jakarta and other areas. Nowadays, 'ojek-online' is widely used, especially in big cities, namely Jabodetabek, Bandung, Surabaya, Bali, and almost every city in Indonesia. Online motorcycle taxis use cloud technology. This technology offers a set of infrastructure services, software, and applications that effectively manage and coordinate data resources to reach a certain scale (Husain \& Budiyantara, 2020). This condition is highly dependent on cloud computing services such as ordering motorcycle taxis using applications included in the category of public clouds.

Previously, motorcycle taxis used an areabased base system at the bends and mouths of alleys. The distribution of motorcycle taxis from other areas cannot be arbitrarily "hung up" in an area without permission from motorcycle taxi riders in that area. Along with technology development, there are currently applications that introduce motorcycle taxi ordering services using technology and service standards (Wuryanti \& Ferani, 2018). To use the motorcycle taxi service, service users have to pay cash and are often offered bargains. Employees who perform well are always the dream of every company to achieve the goals that have been formulated (Martini \& Widyani, 2019). All provide almost the same services, starting from delivering people at different costs 
but with the same ordering system, namely ordering via mobile phone applications and websites (Adi \& Suryawardana, 2018).

The increasing number of online motorcycle taxis has an impact on tighter competition. The factors that cause this are competition for customer satisfaction; there are many online motorcycle taxi service choices. This makes consumers more selective. Consumers will choose one of the alternative options according to what they want (David, 2020:3).

The rapidly growing population of mobile phones makes mobile commerce an important part of today's business strategy, along with the development of wireless technology (Nida, Wirawan, \& Harmana, 2020). Moreover, this is certainly an opportunity even in an economic recession. During the economic crisis, SMEs show survival shreds of evidence since they use local resources unaffected by global macroeconomy instability (Suidarma, Sara, Anggaradana, \& Pratiwi, 2018). Optimistic information society, where application users to transact online tend to visit websites with high traffic regarding access to information with a statistical approach (Husain, Sani, Ardhiansyah, \& Wiliani, 2020). For example, ordering an online motorcycle taxi service is mostly used in Jakarta as a nation's capital of Indonesia. There are currently many online motorcycle taxi service providers that do not have certain rules, both in terms of tariffs, service standards, operating hours, attributes, etc. So that to change this view of service users as unofficial public transportation.

Therefore PT Gojek Indonesia, which has existed since 2010, provides online motorcycle taxi transportation services based on applications under the 'GoJek' brand, equipped with facilities and conditions, namely motorbikes with a minimum production year in 2011. The service quality for motorbike taxi drivers in the Jabodetabek area still frequently occurs violations, for example, drivers who are still found do not use complete attributes, namely 'gojek' jackets, or ripped jackets, and do not use 'gojek' helmets, the pick-up time is still long from the time limit given by companies because drivers ignore the rules, and sometimes the number plates or vehicles used are often different from those in the application, drivers are still found careless or violating regulations in driving.

The importance of service quality by integrating the use of information technology based on the main aspect, namely the ease of use and access, so that it positively affects business growth by using this information technology (Sani et al., 2020).

Service quality is still a problem because there are still violations that occur by drivers who ignore the company's applicable regulations, along with the attachments to the regulations that apply to drivers taken in the applicable regulations of the agreement between drivers and companies. Customer complaint data on Go-Ride services in Jabodetabek in 2020 as follows:

Table 1

Data of customer complaint on Go-Ride's service

\begin{tabular}{|c|c|c|c|c|}
\hline No & $\begin{array}{c}\text { Service } \\
\text { Quality List }\end{array}$ & $\begin{array}{c}\text { Enterprise } \\
\text { Standar }\end{array}$ & $\begin{array}{c}\text { Real } \\
\text { Condition }\end{array}$ & Evidence \\
\hline 1 & $\begin{array}{l}\text { Pick up time } \\
\text { (responsive- } \\
\text { ness) }\end{array}$ & 5 minute & 10 minute & $\begin{array}{l}\text { Long pick- } \\
\text { up time to } \\
\text { customers }\end{array}$ \\
\hline 2 & $\begin{array}{l}\text { One-sided } \\
\text { cancellation } \\
\text { (reliability) }\end{array}$ & $\begin{array}{l}\text { don't } \\
\text { happen }\end{array}$ & $\begin{array}{l}\text { did } \\
\text { happen }\end{array}$ & $\begin{array}{l}\text { Requesting } \\
\text { the order } \\
\text { to be } \\
\text { canceled } \\
\text { by the } \\
\text { driver to } \\
\text { the } \\
\text { customer }\end{array}$ \\
\hline 3 & $\begin{array}{l}\text { Drivers do } \\
\text { not wear } \\
\text { 'Gojek' } \\
\text { attributes } \\
\text { (tangible) }\end{array}$ & $\begin{array}{l}\text { don't } \\
\text { happen }\end{array}$ & $\begin{array}{l}\text { did } \\
\text { happen }\end{array}$ & $\begin{array}{l}\text { Drivers do } \\
\text { not use } \\
\text { complete } \\
\text { attributes } \\
\text { when } \\
\text { executing } \\
\text { orders }\end{array}$ \\
\hline 4 & $\begin{array}{l}\text { Drivers are } \\
\text { less careful } \\
\text { (assurance) }\end{array}$ & $\begin{array}{l}\text { don't } \\
\text { happen }\end{array}$ & $\begin{array}{l}\text { did } \\
\text { happen }\end{array}$ & $\begin{array}{l}\text { Drivers } \\
\text { who are } \\
\text { less careful } \\
\text { in driving }\end{array}$ \\
\hline 5 & $\begin{array}{l}\text { Vehicle } \\
\text { license } \\
\text { plates are } \\
\text { different } \\
\text { (tangible) }\end{array}$ & $\begin{array}{l}\text { don't } \\
\text { happen }\end{array}$ & $\begin{array}{l}\text { did } \\
\text { happen }\end{array}$ & $\begin{array}{l}\text { Using a } \\
\text { vehicle } \\
\text { number } \\
\text { license is } \\
\text { different } \\
\text { from the } \\
\text { one listed } \\
\text { on the } \\
\text { application }\end{array}$ \\
\hline
\end{tabular}

(Primary data processed, 2020)

Seeing that many other online motorcycle taxi competitors have a good brand image, this will be of particular concern for the company PT Gojek Indonesia to pay more attention to a brand's credibility in front of the general public's 
perception. Gojek's strong brand image can compete with their competitors, easy to pronounce words, images or slogans that are always in the mind of customers can help customers to choose the transportation to use when circumstances are urgent to help their choice. Top brand index for online transportation service category on customer assessment, the percentage of Gojek as follows:

Table 2

Top Brand Index for online transportation service

\begin{tabular}{llll}
\multicolumn{1}{c}{ Years } & \multicolumn{1}{c}{$\mathbf{2 0 1 7}$} & $\mathbf{2 0 1 8}$ & \multicolumn{1}{c}{$\mathbf{2 0 1 9}$} \\
\hline Gojek & $59.2 \%$ & $44.9 \%$ & $44.6 \%$ \\
\hline Grab & $28.2 \%$ & $48.0 \%$ & $43.1 \%$ \\
\hline Uber & $8.0 \%$ & & \\
\hline Blue Jek & $0 \%$ & & \\
\hline & & & (TBI Data, 2019)
\end{tabular}

In 2017 Gojek won the top position in customer ratings with Gojek scoring 59.2\%; in 2018, Grab replaced Gojek's top position in the Online Top Brand Index. Transportation Service Category with a value of $48.0 \%$ while Gojek only received a value of $44.9 \%$. The increase in the percentage indicates the existence of great efforts made by competitors to provide a better image in the public's eyes. This phenomenon makes Gojek even more trying to satisfy customers and still reach the top position in the online transportation service category. In 2019 Gojek won the top position again in the Top Brand Index for the online transportation services category. Still, there was a decrease in the percentage from which Gojek initially won $59.2 \%$ in 2017 to $44.6 \%$ in 2019 . The hereditary in the percentage of Gojek since 2017, although still leading the top brand index, is a problem in itself, namely a decrease in customer satisfaction.

According the Lovelock and Wirtz, satisfaction is an attitude that is decided based on the experience gained. Research is needed to prove the presence or absence of previous expectations, which is the most important part of satisfaction (Tjiptono, 2019:74). Based on Delone \& McLean (2003), satisfaction refers to the user's response to the output of an information system which can be measured by the dimensions of repeat purchases, repeat visits, and user surveys (Husain, 2019). Customer satisfaction data on Gojek services in Jabodetabek in 2020 as follows:
Table 3

Data of customer satisfaction on Go-Ride's service

\begin{tabular}{|c|c|c|c|}
\hline No & $\begin{array}{c}\text { Customer } \\
\text { Satisfaction List }\end{array}$ & $\begin{array}{c}\text { Enterprise } \\
\text { Result }\end{array}$ & $\begin{array}{c}\text { Real } \\
\text { Condition }\end{array}$ \\
\hline 1 & $\begin{array}{l}\text { Conformity } \\
\text { Expectations; } \\
\text { The level of } \\
\text { conformity } \\
\text { between } \\
\text { expected service } \\
\text { performance }\end{array}$ & $\begin{array}{l}\text { Growing } \\
\text { customer trust } \\
\text { in the services } \\
\text { provided by } \\
\text { Gojek }\end{array}$ & $\begin{array}{l}\text { Gojek drivers } \\
\text { have not } \\
\text { provided the } \\
\text { best service } \\
\text { when } \\
\text { ordering } \\
\text { orders }\end{array}$ \\
\hline 2 & $\begin{array}{l}\text { Reuse } \\
\text { Customers'; } \\
\text { Availability to } \\
\text { use Go-Ride's } \\
\text { services again }\end{array}$ & $\begin{array}{l}\text { There is an } \\
\text { expectation } \\
\text { that customers } \\
\text { will use Go- } \\
\text { Ride's } \\
\text { services again }\end{array}$ & $\begin{array}{l}\text { Customers } \\
\text { don't trust } \\
\text { Go-Ride's } \\
\text { services, so } \\
\text { they often use } \\
\text { other online } \\
\text { motorcycle } \\
\text { taxis }\end{array}$ \\
\hline 3 & $\begin{array}{l}\text { Willingness to } \\
\text { Recommend } \\
\text { The existence } \\
\text { of good } \\
\text { judgments that } \\
\text { are discussed } \\
\text { with others } \\
\text { (tangible) }\end{array}$ & $\begin{array}{l}\text { The } \\
\text { willingness of } \\
\text { customers to } \\
\text { recommend } \\
\text { services that } \\
\text { have been } \\
\text { perceived }\end{array}$ & $\begin{array}{l}\text { Customers } \\
\text { are reluctant } \\
\text { to } \\
\text { recommend } \\
\text { to other Go- } \\
\text { Ride }\end{array}$ \\
\hline
\end{tabular}

Customers are not satisfied with the quality of service provided by Gojek to customers. There are still many indicators of service quality carried out by Gojek drivers that are still ignored, causing decreased customer satisfaction, and Gojek customers still do not feel pleasure after using Go-Ride's services.

This research examines how online customer satisfaction predicts service quality and brand image of Go-Ride services in the Jabodetabek area and the influence of both.

\section{CONCEPT AND HYPOTHESIS}

Service quality defined as a brand image will affect the level of customer satisfaction in enjoying a product and service (Tjiptono, 2019:59). This study's service quality uses five dimensions to evaluate service quality according the Valarie Zeithaml, Mary Jo Bitner and Dwayne Gremler (2018), with the term TERRA, which consists of Tangible, Empathy, Responsiveness, Reliability, and Assurance (Hanny \& Jayadih, 2020).

A brand image is a set of brand associations formed and stuck in consumers' minds. Consumers who are accustomed to using certain brands tend to have consistency with the brand image (Rangkuti, 2009:244), when consumers' lives become increasingly complicated, rushed, 
and time-consuming, brands' ability to simplify decision-making and reduce risk is valuable (Kotler \& Keller, 2014:264).

The brand image owned by Gojek is perfect compared to other transportation companies; this shows that Gojek does have good quality, price, and brand image so that it can provide customer satisfaction (Kurnia, 2018). This study's brand image uses two indicators, i.e.: (1) The excellence of brand association is one of the factors forming a brand image, where the product is superior in competition; (2) The brand association's strength is how information enters consumers' memories and how the process survives as part of the brand image. That is what will continue to be the link between the product/brand and the consumer. Thus the brand will be quickly recognized and maintained in the midst of intense competition; and (3). The uniqueness of the brand association, which is the product's uniqueness towards a brand, inevitably has to be shared with other brands. Therefore, competitive advantage must be created to be used as an excuse for consumers to choose a particular brand (Kotler \& Keller, 2014:347).

Customer satisfaction is a person's feeling of pleasure or disappointment resulting from comparing the perceived product performance (or results) with the expected expectations (Tjiptono, 2019:138). This study's customer satisfaction uses two indicators, i.e.: (1) The conformity of expectations is the level of conformity between the service performance expected by the customer, and that felt by the customer; (2) Reusing is the customer's willingness to visit again or reuse related services; and (3) Willingness to recommend is a customer's willingness to recommend a service that has been felt to friends or family (Tjiptono, 2019).

As a reference for this study's comparison, a study was carried out on previous research that was relevant according to the research data, title including the variables used in the research. Several previous research findings state that: (1) Kurnia and Puspaningrum's research in the 2018 year about online transportation service users' satisfaction in Malang City using service quality factors, price, and brand image involving 140 respondents of Gojek consumers. The research findings prove that service quality, price, and brand image positively and significantly affect customer satisfaction, with the brand image factor that has the most dominant influence. (2) Adi dan Suryawardana's research in the 2018 year about consumer behavior in using online 'ojek' transportation services in Semarang using internal and external factors involving five informants of Gojek consumers. The results showed that consumer behavior is influenced by internal factors such as work, lifestyle, past experiences, and passion, while external factors are influenced by friends, promotion, price, and service. (3) Wuryanti and Ferani's research in the 2018 year about customer satisfaction of service users at SMK Trisakti Bandar Lampung using service quality factors, price perception, and brand awareness involving 140 respondents Gojek customers. The research findings prove that service quality, price perception, and brand image are positively and significantly related to customer satisfaction. (4) Ihsan and Siregar's research in the 2019 year about customer satisfaction of service online 'ojek' transportation services in Jambi using e-service quality through consumer trust factors involving 150 people Gojek customers. The research findings prove that e-service quality and consumer trust have a significant effect on Go-jek online motorcycle user decisions. (5) David's research in the 2020 year about customer satisfaction of Gojek in Palembang City using service quality factors, price, brand image, and easiness involving 180 sample Go-Ride and Go-Car user's. The research findings prove that service quality, price, brand image, and easiness have a partially and simultaneosly effect on customer satisfaction.

Hypothesis development is needed to formulate the prediction of online customer satisfaction, how service quality and brand image. Hypothesis is a temporary answer to the formulation of research problems because it is only based on relevant theories and has not been based on empirical data collection facts (Sugiyono, 2017:63). Development of alternative hypothesis in this study stated as follows: (1) $\mathrm{H} 1, \mathrm{H} 2$, each one of the service quality, and brand image influences online customer satisfaction 'Go-Ride' transportation services in Jabodetabek area; and (2) H3 equally on service quality, and brand image have an influence towards online customer satisfaction 'Go-Ride' transportation services in Jabodetabek area. 


\section{METHOD}

This variety of causation study based in serving explanations and measuring the factitives influence link among variables as a basis for anatomizing several of these variables (Supranto \& Limakrisna, 2019:13). The investigation takes a quantitative oncoming with populations are passengers of Go-Ride services, which is located at Pasaraya Blok M, Building $\mathrm{B}, 4^{\text {th }}$ Floor Jl. Iskandarsyah II No.2, Melawai Kebayoran Baru, South Jakarta, DKI Jakarta, 12160. The research was conducted for five months starting from July to November 2020 and use a questionnaire tool with a Likert scale. Research sample use a purposive sampling with minimum requisite for two times the customer used Go-Ride's services by Roa Purba calculation as the amount of 96 respondent. Operationalization of variables as follows:

Table 4

Operationalization of Variables

\begin{tabular}{|c|c|c|c|}
\hline Abb. & Variables & Indicators & Items \\
\hline \multirow[t]{5}{*}{$\mathrm{X} 1$} & Service & 1. Tangible & 1,2 \\
\hline & Quality & 2. Reliability & 3,4 \\
\hline & & 3. Responsiveness & 5,6 \\
\hline & & 4. Assurance & 7,8 \\
\hline & & 5. Empathy & 9,10 \\
\hline \multirow[t]{3}{*}{$\mathrm{X} 2$} & $\begin{array}{l}\text { Brand } \\
\text { Image }\end{array}$ & $\begin{array}{l}\text { 1. The excellence of } \\
\text { brand association }\end{array}$ & $1,2,3,4$ \\
\hline & & $\begin{array}{l}\text { 2. The brand association's } \\
\text { strenght }\end{array}$ & $5,6,7$ \\
\hline & & $\begin{array}{l}\text { 3. The uniqueness of the } \\
\text { brand association }\end{array}$ & $8,9,10$ \\
\hline \multirow[t]{3}{*}{$\mathrm{Y}$} & $\begin{array}{l}\text { Online } \\
\text { Customer }\end{array}$ & $\begin{array}{l}\text { 1. The conformity of } \\
\text { expectations }\end{array}$ & $1,2,3,4$ \\
\hline & Satisfaction & 2. Reusing & $5,6,7$ \\
\hline & & $\begin{array}{l}\text { 3. Willingness to } \\
\text { recommend }\end{array}$ & $8,9,10$ \\
\hline
\end{tabular}

Data analysis method in this study using the aid of the SPSS for Windows Program. Instrument testing consists of a validity test that uses a product-moment, and the reliability test uses Cronbach's alpha coefficient. The classical assumption test is done to requirement BLUE (best, linear, unbiased, and estimator) before hypothesis testing. Regression analysis technique using multiple regression with compute as $\mathrm{Y}=\alpha+\beta 1 \mathrm{X} 1+\beta 2 \mathrm{X} 2+\ldots . . \beta \mathrm{nXn}$.

\section{RESULT AND DISCUSSION \\ 1. Overview of Research Objects}

Go-jek was founded by Nadiem Makarim, an Indonesian citizen who graduated with a
Master of Business Administration from Harvard Business School. The idea of establishing Go-jek arose from the personal experience of Nadiem Makarim, who used to take motorcycle taxis almost every day to work to get through traffic jams in Jakarta. At that time, Nadiem was still working as the CoFounder and Managing Editor of Zalora Indonesia and Chief Innovation Officer Kartuku.

As someone who frequently uses Go-Ride services, Nadiem apparently sees that most of the time spent by 'ojek' drivers is just hanging around waiting for passengers. Besides, he sees that the availability of this type of transportation is not as much as other types of transportation, so it is often quite difficult to find. He wants an ojek that is usually there when needed. Starting from this, Nadiem created a service that could connect passengers with motorcycle taxi drivers.

\section{Validity and Reliability Test Yields}

Table 5

Validity Test Yields

\begin{tabular}{|c|c|c|c|}
\hline Abb. & Variables | Items Numbers & R-Score & Yields \\
\hline \multirow{15}{*}{$\mathrm{X} 1$} & Tangible & & \\
\hline & 1 & 0.691 & valid \\
\hline & 2 & 0.661 & valid \\
\hline & Reliability & & \\
\hline & 3 & 0.629 & valid \\
\hline & 4 & 0.649 & valid \\
\hline & Responsiveness & & \\
\hline & 5 & 0.688 & valid \\
\hline & 6 & 0.502 & valid \\
\hline & Assurance & & \\
\hline & 7 & 0.603 & valid \\
\hline & 8 & 0.516 & valid \\
\hline & Empathy & & \\
\hline & $9+2$ & 0.603 & valid \\
\hline & 10 & 0.494 & valid \\
\hline \multirow[t]{13}{*}{$\mathrm{X} 2$} & $\begin{array}{l}\text { The excellence of brand } \\
\text { association }\end{array}$ & & \\
\hline & 1 & 0.708 & valid \\
\hline & 2 & 0.659 & valid \\
\hline & 3 & 0.652 & valid \\
\hline & 4 & 0.714 & valid \\
\hline & $\begin{array}{l}\text { The brand association's } \\
\text { strenght }\end{array}$ & & \\
\hline & 5 & 0.661 & valid \\
\hline & 6 & 0.557 & valid \\
\hline & 7 & 0.473 & valid \\
\hline & Empathy & & \\
\hline & 8 & 0.525 & valid \\
\hline & 9 & 0.423 & valid \\
\hline & 10 & 0.482 & valid \\
\hline \multirow[t]{3}{*}{$\bar{Y}$} & $\begin{array}{l}\text { The conformity of } \\
\text { expectations }\end{array}$ & & \\
\hline & 1 & 0.512 & valid \\
\hline & 2 & 0.721 & valid \\
\hline
\end{tabular}

Page 43 


\begin{tabular}{|c|c|c|c|}
\hline Abb. & Variables | Items Numbers & R-Score & Yields \\
\hline & 3 & 0.602 & valid \\
\hline & 4 & 0.709 & valid \\
\hline \multicolumn{4}{|c|}{ Reusing } \\
\hline & 5 & 0.676 & valid \\
\hline & 6 & 0.743 & valid \\
\hline & 7 & 0.815 & valid \\
\hline \multicolumn{4}{|c|}{$\begin{array}{l}\text { Willingness to } \\
\text { recommend }\end{array}$} \\
\hline & 8 & 0.724 & valid \\
\hline & 9 & 0.730 & valid \\
\hline & 10 & 0.754 & valid \\
\hline
\end{tabular}

The validity test results using $\mathrm{dF}(\mathrm{n}-\mathrm{k})=$ 96-3, i.e. 93 yielding an R-table of 0.2017. All items in each variable's statement have an RScore that is greater than the R-table, meaning that all items in the questionnaire statement are valid.

Table 6

Reliability Test Yields

\begin{tabular}{lcc}
\hline \multicolumn{1}{c}{ Variables | Items Amount } & $\begin{array}{c}\text { Cronbach's } \\
\text { Alpha }\end{array}$ & Yields \\
\hline Service Quality (10 items) & 0.748 & Reliable \\
\hline Brand Image (10 items) & 0.744 & Reliable \\
\hline $\begin{array}{l}\text { Online Customer Satisfaction } \\
\text { (10 items) }\end{array}$ & 0.768 & Reliable \\
\hline & & \\
\hline
\end{tabular}

The reliability test results using each of the 10 items constructs, i.e., service quality, brand image, and customer satisfaction, have Cronbach's alpha is greater than 0.6, meaning that all variables in the construct of this research are reliable.

\section{Classical Assumption Test Yields}

The classical assumption test yields normality as follow:

Image 1

Normal P-Plot

(Source: Output from SPSS, 2020)

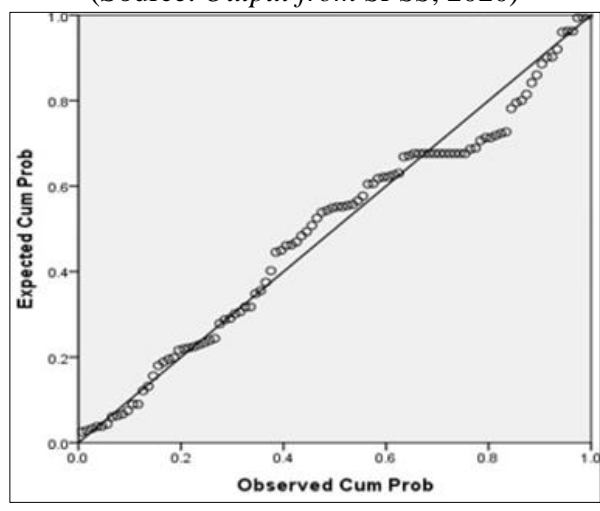

The curve analysis (P-Plot) shows that the regression model fulfills the normality assumption. It can be seen that the dots spread around a diagonal line or spread out following a diagonal line and follow a regression model.

Table 7

VIF and Tolerance Score

\begin{tabular}{lcc}
\hline Independent Variables & $\begin{array}{c}\text { Tolerance } \\
\text { Score }\end{array}$ & $\begin{array}{c}\text { VIF } \\
\text { Score }\end{array}$ \\
\hline Service Quality & 0.743 & 1.346 \\
\hline Brand Image & 0.743 & 1.346 \\
\hline & (own recapitulated, 2020)
\end{tabular}

The tolerance score is 0.743 , which means that it is less than 0.10 , and the VIF score is 1.346, which means less than 10. The two independent variables above do not experience multicollinearity symptoms.

Table 8

\begin{tabular}{lc}
\multicolumn{2}{c}{ The Glejser Test Yields } \\
\hline \multicolumn{1}{c}{ Variables } & $\begin{array}{c}\text { Sig. } \\
\text { Probability }\end{array}$ \\
\hline Constant & 0.155 \\
\hline Service Quality & 0.219 \\
\hline Brand Image & 0.451 \\
\hline \multicolumn{2}{l}{ (own recapitulated, 2020) }
\end{tabular}

The two variables' constant and significant scores are 0.219 , and 0.451 is more than 0.05 , respectively, so it can be concluded that the data does not have heteroscedasticity problems.

\section{Hypothesis Test Yields}

The hypothesis test yields begin with a determination of coefficients test as follow:

Table 9

Determination Coefficient Test Yields

\begin{tabular}{cccc}
\hline Model & R & R-Square & Std. Error \\
\hline 1 & 0.743 & 0.552 & 2.81266 \\
\hline \multicolumn{3}{c}{ (own recapitulated, 2020) }
\end{tabular}

The determination of coefficient test results produces an $\mathrm{R}$ score is 0.743 , meaning that strong relationship between service quality and brand image with online customer satisfaction. The R-square score is 0.552 , meaning that 55.2 percent contribution of service quality and brand image predicts online customer satisfaction in this study, and 44.8 percent is predicted by other factors outside of this research model. 


\begin{tabular}{cccl}
\hline \hline & \multicolumn{3}{c}{ Table 10 } \\
& F-Test Yields \\
\hline Model & df & F-Stats. & Sig. Probability \\
\hline $\begin{array}{c}\text { 1| Regression } \\
\text { Residual }\end{array}$ & 2 & 57.336 & 0.000 \\
\hline \multicolumn{4}{c}{ (own recapitulated, 2020) }
\end{tabular}

The F-test results produce a score is 57.336 using df 1 is ' 2 ', df 2 is ' 93 ', yielding an F-table of 3.094 or with significant probabilities is 0.000 , meaning that F-Stats is greater than the Ftable and ha rejected, meaning that service quality and brand image have the ability to predict online customer satisfaction in this study.

Table 11

t-Test Yields

\begin{tabular}{llll}
\hline $\begin{array}{c}\text { Abb. } \\
\text { Hypothesis }\end{array}$ & \multicolumn{1}{c}{ Variables } & t-Stats. & $\begin{array}{c}\text { Sig. } \\
\text { Probability }\end{array}$ \\
\hline & Constant & 0.522 & 0.603 \\
\hline H1 & Service Quality & 4.330 & 0.000 \\
\hline H2 & Brand Image & 6.248 & 0.000 \\
\hline \multicolumn{4}{c}{} \\
\end{tabular}

Based on the regression model above, the yields of the regression equation, viz:

$\mathrm{Y}=1.818+0.357 \mathrm{X} 1+0.559 \mathrm{X} 2$.

\section{Discussions}

According to the t-Test yields (table 11), the $\mathrm{t}$-Stats score is (4.330) for service quality factors with significant probabilities is 0.000 . This score is greater than the t-table (1.9858) or less than 0.05 of the significant probabilities value, so $\mathrm{H} 1$ is accepted. It means that the service quality influences online customer satisfaction 'Go-Ride' transportation services in the Jabodetabek area. These yields align with the findings on the service quality able to influence customer satisfaction (David, 2020; Kurnia, 2018; Wuryanti \& Ferani, 2018), and also services through external factors (Adi \& Suryawardana, 2018) while e-service quality (Ihsan \& Siregar, 2019), service quality in this study still is trusted by online customer Go-Ride products because it becomes the main requirement of every consumer who has the advantage of technology and ease of use of features in this application. On the other side, sometimes, violations occur by drivers who ignore the company's applicable regulations. This condition is evidenced by online customer satisfaction, which strongly predicts service quality.

According to the t-Test yields (table 11), the $\mathrm{t}$-Stats score is (6.248) for service quality factors with significant probabilities is 0.000 . This score is greater than the t-table (1.9858) or less than 0.05 of the significant probabilities value, so $\mathrm{H} 2$ is accepted. It means that the brand image influences online customer satisfaction 'Go-Ride' transportation services in the Jabodetabek area. These yields align with the findings on the brand image able to influence customer satisfaction (David, 2020; Kurnia, 2018), and also brand awareness (Wuryanti \& Ferani, 2018). Brand image in this study upon Go-Ride's product since three years ago still strongly compared with their competitors (Top Brand Award, 2019). Increasingly complex consumer activity for rushed and time-consuming things, the ability of brands to simplify decision-making and reduce risk is invaluable because it is embedded in consumers' minds, especially customers (Kotler \& Keller, 2014:264).

According to the F-Test yields (table 10), the F-Stats score is (57.336) for service quality and brand image factors with significant probabilities is 0.000 . This score is greater than the F-table (3.094) or less than 0.05 of the significant probabilities value, so $\mathrm{H} 3$ is accepted. It means that the service quality and brand image influences online customer satisfaction 'Go-Ride' transportation services in the Jabodetabek area simultaneously. These yields align with the findings on the both of them factors able to influence customer satisfaction (David, 2020; Kurnia, 2018; Wuryanti \& Ferani, 2018). The contribution of service quality and brand image predicts that online customer satisfaction yields 55.2 percent to predict online customer satisfaction in this study, meaning that both factors dominate online customer satisfaction of Go-Ride products.

\section{CONCLUSION}

The results and discussion use online customer satisfaction based on the service quality and brand image as a study Go-Ride services yields impact partially and simultaneously. This is also reinforced by online customer satisfaction contributing 55.2 percent to predict service quality and brand image in this study.

The suggestion of this study i.e. (1) there needs to be more attention from the company regarding the quality of service provided by drivers to customers, with drivers always carrying out their orders without having to ask 
for orders to be canceled from customers, so that customers always trust and are satisfied with the services provided by Gojek drivers; (2) Go-Ride services further enhance the Gojek brand's image so that it creates a sense of pride in the minds of customers and becomes the main choice when customers think of online motorcycle taxi brands, so customers decide always to use Gojek product; and (3) PT Gojek Indonesia must pay more attention to the service quality from Gojek drivers to customers and improve the Gojek brand image in the minds of customers so that customers feel proud, and get new customers if they want to travel, or always use motorbike taxi services repeatedly.

\section{REFERENCES}

Adi, V. B., \& Suryawardana, E. (2018). Perilaku Konsumen dalam Menggunakan Jasa Transportasi Ojek Online di Semarang. Majalah Ilmiah Solusi, 16(4), 59-78.

David. (2020). Pengaruh Kualitas Pelayanan, Harga, Citra Merek, dan Kemudahan terhadap Kepuasan Pelanggan Gojek di Kota Palembang. Palembang: STIE Multi Data Palembang.

Delone, W. H., \& McLean, E. R. (2003). The DeLone and McLean Model of Information Systems Success: A Ten-Year Update. Journal of Management Information Systems, 19(4), 930.

Fatimah, S. (2019). Pengantar Transportasi. Ponorogo: Myria Publisher.

Hanny, R., \& Jayadih, T. (2020). The Effect of Service Quality to the Costumer Satisfaction on Domino's Pizza Branch Grand Centro Bintaro, South Jakarta. Sosio E-Kons, 12(2), 97-106.

Husain, T. (2019). Analisis Layanan Google Scholar Sebagai Bahan Referensi Terhadap Kepuasan Mahasiswa. ULTIMA InfoSys: Jurnal Sistem Informasi, 10(1), 69-75.

Husain, T., \& Budiyantara, A. (2020). Analysis of Control Security and Privacy Based on eLearning Users. SAR Journal, 3(2), 51-58.

Husain, T., Sani, A., Ardhiansyah, M., \& Wiliani, N. (2020). Online Shop as an Interactive Media Information Society based on Search Engine Optimization (SEO). International Journal of Computer Trends and Technology (IJCTT), 68(3), 53-57.

Ihsan, M., \& Siregar, A. P. (2019). Pengaruh Eservice Quality Terhadap Keputusan Pengguna Jasa Ojek Online Go-Ride dalam Aplikasi GoJek melalui Kepercayaan Konsumen di Kota Jambi. J-MAS (Jurnal Manajemen Dan Sains), 4(1), 170-175.
Kotler, P. T., \& Keller, K. L. (2014). Marketing Management (14th ed.). New Jersey: Pearson Prentice Hall.

Kurnia, S. C. (2018). Pengaruh Kualitas Pelayanan, Harga dan Citra Merek terhadap Kepuasan Pelanggan Pengguna Jasa Transportasi Ojek Online (Studi Pada Pelanggan Gojek di Kota Malang). Jurnal Ilmiah Mahasiswa FEB Universitas Brawijaya, 6(2), 1-12.

Martini, L. K. B., \& Widyani, A. A. D. (2019). Effects of Empowerment, Work Climate and Job Satisfaction on Employee Performance of Transportation Office of Klungkung Regency. Jurnal Ekonomi Dan Bisnis JAGADITHA, 6(2), 99-103.

Nida, D. R. P. P., Wirawan, I. M. D. S., \& Harmana, I. M. D. (2020). The Influencing Factors toward Universitas Warmadewa Student Interests in Using Mobile Commerce. Jurnal Ekonomi Dan Bisnis JAGADITHA, 7(2), 104113.

Rangkuti, F. (2009). Strategi Promosi yang Kreatif dan Analisis Kasus Integrated Marketing Communications. Jakarta: Gramedia Pustaka Utama.

Sani, A., Pusparini, N. N., Rizal, Khristiana, Y., Zailani, A. U., \& Husain, T. (2020). E-Business Adoption Models in Organizational Contexts on The TAM Extended Model: A Preliminary Assessment. In 8th International Conference on Cyber and IT Service Management (CITSM 2020). Pangkalpinang: IEEE.

Sugiyarto, S., Dewi, D. P., \& Junaedi, E. (2020). Pengaruh Moda Transportasi Berbasis Aplikasi terhadap Pilihan Masyarakat dalam Menentukan Moda Transportasi dan Dampaknya terhadap Pendapatan Driver Ojek Online. DERIVATIF: Jurnal Manajemen, 14(2), 138-150.

Sugiyono. (2017). Metode Penelitian Evaluasi: Pendekatan Kuantitatif, Kualitatif, dan Kombinasi. Bandung: CV. Alfabeta.

Suidarma, I. M., Sara, I. M., Anggaradana, I. N., \& Pratiwi, I. G. A. M. A. A. (2018). The Convergence of Beta Credit for Micro, Small and Medium Enterprises (MSMEs) in Indonesia's Provinces. International Journal of Finance \&Amp; Banking Studies (2147-4486), 7(1), 33-42.

Supranto, J., \& Limakrisna, N. (2019). Petunjuk Praktis Penelitian Ilmiah untuk Menyusun Skripsi, Tesis dan Disertasi (5th ed.). Bogor: Mitra Wacana Media.

Tjiptono, F. (2019). Pemasaran Jasa: Prinsip, Penerapan, dan Penelitian (Cetakan 1) (II Ed.). Yogyakarta: Penerbit Andi.

Wuryanti, L., \& Ferani, F. (2018). Pengaruh Kualitas Pelayanan, Persepsi Harga, dan Kesadaran 
Merek terhadap Kepuasan Pelanggan Pengguna

Jasa Transportasi Ojek Online (Studi Pada Pelanggan Go-Jek dan Grab di SMK Trisakti Bandar Lampung). Jurnal Riset Akuntansi Dan Manajemen Malahayati, 7(2), 92-99.

Top Brand Award. (2019). Accordion \#1. Accessed on September 2020, dari BRAND TBI 2017, 2018, 2019: https://www.topbrandaward.com/en/2019/07/jasa-transportasi-onlinefase-2-2019/; https://www.topbrandaward.com/en/2018/07/jasa-transportasi-online2018/; $\quad$ https://www.topbrandaward.com/en/2017/07/jasa-transportasi-onlinefase-2-2017 